\title{
The Effect of Work Culture and Job Stress on Work Effectiveness PT Trakindo Utama Branch Palembang
}

\author{
Debby Anggraini, Agustina Hanafi, Yuliani
}

\begin{abstract}
This study consists of independent variables, namely work culture (X1) and work stress (X2) and the dependent variable $(Y)$ is the work effectiveness of employees of PT Trakindo Utama Palembang branch. The results of initial observations and interviews with the human resources division of PT Trakindo Utama, several factors that affect work effectiveness are work culture and work stress. Work culture is a set of assumptions or belief systems, values and norms developed in an organization that is used as a behavioral guide for its members to overcome problems of external adaptation and internal integration. One of the principles of work culture that can be used is the $5 S$ principle which consists of aspects of seiri, seiton, seiso, seiketsu, setsuke which come from Japan and have been widely used in many large companies around the world. Based on the results of interviews with the human resources division of PT Trakindo Utama in addition to work culture which is the influence of work effectiveness, work stress can also affect employee work effectiveness. The cause of stress is anything that causes stress, which is commonly referred to as a stressor. The sampling method was purposive sampling with a sample of 60 respondents with multiple linear regression SPSS software version 26 . The results showed that work culture had a positive and significant influence on work effectiveness and work stress had a negative influence on work effectiveness at PT Trakindo Utama.
\end{abstract}

Keywords: Work Culture, Job Stress, Work Effectiveness

\section{INTRODUCTION}

An organizational success, both large and small, is not solely determined by the available natural resources, but is largely determined by the quality of human resources (HR) who play a role in planning, implementing and controlling the organization concerned (Sutrisno, 2012). An organization, both private and government, must go through the means in the form of an organization that is driven by a group of people who play an active role as actors in achieving the goals of the organization concerned (Andriani et al., 2019).

Manuscript received on June 03, 2021.

Revised Manuscript received on June 24, 2021.

Manuscript published on June 30, 2021.

* Correspondence Author

Debby Anggraini*, Student Magister Management , Economic Faculty of Sriwijaya University, Palembang, Indonesia Email: debbyanggraini1095@gmail.com

Agustina Hanafi, Lecturer of Magister Management, Economic Faculty, Sriwijaya University, Palembang Indonesia

Yuliani, Lecturer of Magister Management, Economic Faculty, Sriwijaya University, Palembang Indonesia

(C) The Authors. Published by Blue Eyes Intelligence Engineering and Sciences Publication (BEIESP). This is an open access article under the CC BY-NC-ND license (http://creativecommons.org/licenses/by-nc-nd/4.0/)

\section{LITERATURE REVIEW}

\section{A. Definition of Work Culture}

Work culture is a set of assumptions or belief systems, values and norms developed within the organization that serve as guidelines for behavior for its members to overcome problems of external adaptation and internal integration (Mangkunegara, 2013). The company's work culture is often reflected in the work behavior of employees, so that companies that have a good and strong culture will have an impact on good performance by employees, which will further improve overall company performance (Gibson, 2003).

\section{B. Definition of Job Stress}

According to Robbins \& Judge (2017), employee job stress is a condition that arises from interactions between humans and work and is characterized by human changes that force them to deviate from their normal functions. Sopiah (2008) stress is an adaptive response to a threatening or challenging situation. Job stress is also defined as a dangerous physical and emotional response that can occur while doing work. Stressful conditions will make a person feel uncomfortable at work and lose motivation, resulting in decreased productivity and effectiveness at work.

\section{Definition of Work Effectiveness}

Yazid (2009: 49) This can be influenced by several factors, namely quality of work, quantity of work, timeliness and targets. Work effectiveness is the appearance of the employee's work both in quality and quantity. Based on the results of preliminary observations and interviews with the human resources division of PT Trakindo Utama, Palembang branch, several factors affect work effectiveness, namely work culture and work stress.

\section{Conceptual Framework}

Research aims to determine the effect of thevariable independentt work culture and work stress on thevariable dependent work effectiveness. The following is figure 2.1 of the research framework.

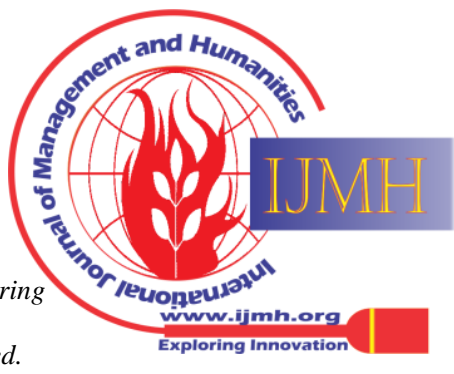




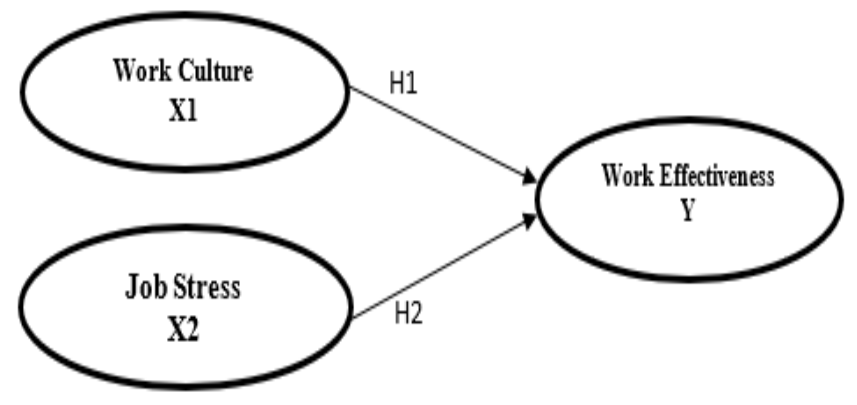

Source : Developed for this research, 2021

Figure 1. Conceptual Framework

Ho1 : Work culture affects the work effectiveness of PT Trakindo Utama Palembang branch

Ha1 = Work culture has no influence on the work effectiveness of PT Trakindo Utama Palembang branch

Ho2 = Work stress affects the work effectiveness of PT Trakindo Utama Palembang Branch

Ha2 = Work stress has no impact on the effectiveness of the work of PT Trakindo Utama Palembangbranch

\section{RESEARCH METHODS}

\section{A. Scope}

The scope discussed in this study are two independent variables, namely work culture (X1) and job stress (X2) and the dependent variable, namely the work effectiveness of the employees of PT Trakindo Utama Palembang branch.

\section{B. Population and Sample}

Total population in this study were all employees who worked in the office PT Trakindo Utama Palembang, totaling 60 employees. The sample determination technique is by means of saturated samples. According to Sugiyono (2017) saturated sample is a sampling technique by taking all members of the population as respondents or samples. Thus, the sample in this study amounted to 60 employees.

\section{Types and Sources of Data}

Types of data used in this study are quantitative data. Quantitative data is data that is measured on a numeric or numeric scale (Sugiyono, 2017). In this study, the results obtained from the answers to the questionnaire using ascale Likert are ordinal data.

The data used in this study were obtained from a questionnaire given to employees of PT Trakindo Palembang Palembang branch.

\section{Data Analysis Techniques}

Test of this research instrument was carried out by giving a questionnaire directly to the respondent. The criteria for a good questionnaire are validity and reliability.

\section{E. Validity Test}

The validity test is intended to find out how much accuracy a measuring instrument is in performing its measuring function. The validity test as a measuring tool in this study is by correlating each question with a total score, then the correlation results are compared with the critical number with a significant level of $5 \%$. In this study, validity testing was carried out on three variables, namely Work Culture (X1), Work Stress (X2) and Work Effectiveness (Y).

\section{F. Reliability test}

Intended to test the consistency of the questionnaire in measuring a similar construct or the stability of the questionnaire if it is used from time to time (Ghozali, 2016). In this case, if the Realibility Coefficient (Alpha) value is greater than $0.60(\alpha>0.6)$, then the variables and items being measured can be trusted or relied upon (Sugiyono, 2017). This study uses 3 variables, namely thevariable independent work culture and work stress, and thevariable dependent work effectiveness.

\section{Research Data Analysis}

Multiple linear regression analysis is used to measure the effect of more than one predictor variable (independent variable) on the dependent variable. The variables used in this research are work culture variable (X1) and job stress variable (X2) to work effectiveness (Y).

Multiple linear regression analysis using the following regression equation:

Where:

Dimana:

$$
\mathbf{Y}=\mathbf{a}+b_{1} X_{1}+b_{2} X_{2}+\mathbf{e}
$$

$\mathrm{Y}=$ Work Effectiveness

$X_{1}=$ Variabel Budaya Kerj

$X_{2}=$ Variabel Stres Kerja

$\mathrm{a}=$ konstanta

$b_{1}=$ Koefisien regresi

$\mathrm{e}=$ Error

\section{G. Hasil Uji Normalitas}

According to Ghozali (2016), the normality test is carried out to test whether a regression model, an independent variable and a dependent variable or both have a normal or abnormal distribution.

\section{H. Multicollinearity test}

Aims to test whether the regression method found a correlation betweenvariables independent. A good regression model should not have a correlation between thevariables independent. The multicollinearity test is carried out by looking at the tolerance value and inflation factor (VIF) and the results of the analysis using the SPSS application. If the tolerance value $<0.1$ and VIF $>10$, it can indicate multicollinearity (Hidayat, 2017).

\section{Heteroscedasticity test}

The heteroscedasticity test is a test that assesses whether there is an inequality of variance of the residuals for all observations in the linear regression model. This test is one of the classic assumption tests that must be done in linear regression. If the assumption of heteroscedasticity is not fulfilled, the regression model is declared invalid as a forecasting tool (Hidayat, 2017).

Published By:

Blue Eyes Intelligence Engineering

\& Sciences Publication

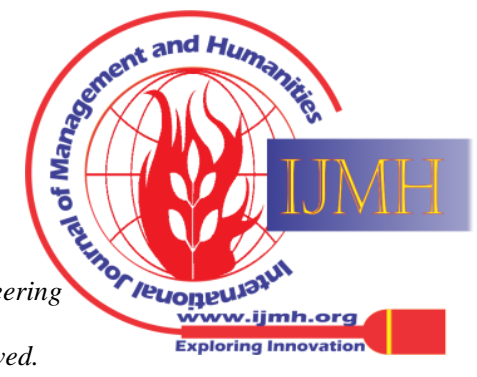




\section{J. T test: Partial Test}

This test is conducted to determine the effect and significance of each independent variable on thevariable dependent. Hypothesis testing of the regression coefficient individually is done by comparing between tcount $>$ ttable. To determine the value of $t$ table is determined with a significant level (a) 0.05 with a degree of magnitude $\mathrm{df}=\mathrm{nk}$, where $\mathrm{n}$ is the number of respondents and $\mathrm{k}$ is the number of variables (Ghozali, 2016).

The test criteria used are as follows:

a. If tcount $>$ ttable, then $\mathrm{HO}$ is rejected and $\mathrm{Ha}$ is accepted

b. If tcount <ttable, then $\mathrm{HO}$ is accepted and Ha is rejected.

$\mathrm{HO}$ is rejected, it means that there is no significant effect of the independent variable on the dependent variable, while Ha is accepted, it means that there is an influence from the independent variable on the dependent variable.

\section{RESULT AND DISCUSSION}

\section{A. Research Instruments Test Result Validity Test}

Test is done by comparing the value of Pearson's Product Moment found in the results of data processing with the help of the SPSS program, seen in the CITS (columnCorrected Item-Total Correlation)with the r value in the PMM (Pearson Product Pomenttable). The critical value of correlation (r-table) with $\mathrm{n}$ is 60 respondents at a significance level of (a) $5 \%$ with the calculation of $\mathrm{df}=(\mathrm{n}-2)$, that is, 58 respondents is 0.2126 in ther table pearson product moment. The criteria for decision making:

l If (r-count) is greater than (r-table) 0.2126, then it is declared valid

If (r-count) is less than (r-table) 0.2126, then it is declared invalid Table Tabel I

Results of the Research Instrument Variable Validity Test

\begin{tabular}{|c|c|c|c|c|}
\hline No. & Indikator & Kode & rHitung & Keterangan \\
\hline 1 & \multirow{21}{*}{ Budaya Kerja (X1) } & BK1 & 0.571 & Valid \\
\hline 2 & & $\mathrm{BK} 2$ & 0.551 & Valid \\
\hline 3 & & BK3 & 0.553 & Valid \\
\hline 4 & & BK4 & 0.592 & Valid \\
\hline 5 & & BK5 & 0.628 & Valid \\
\hline 6 & & BK6 & 0.741 & Valid \\
\hline 7 & & BK7 & 0.545 & Valid \\
\hline 8 & & BK8 & 0.674 & Valid \\
\hline 9 & & BK9 & 0.675 & Valid \\
\hline 10 & & BK10 & 0.609 & Valid \\
\hline 11 & & BK11 & 0.605 & Valid \\
\hline 12 & & BK12 & 0.602 & Valid \\
\hline 13 & & BK13 & 0.567 & Valid \\
\hline 14 & & BK14 & 0.600 & Valid \\
\hline 15 & & BK15 & 0.700 & Valid \\
\hline 16 & & BK16 & 0.585 & Valid \\
\hline 17 & & BK17 & 0.628 & Valid \\
\hline 18 & & BK18 & 0.550 & Valid \\
\hline 19 & & BK19 & 0.558 & Valid \\
\hline 20 & & $\mathrm{BK} 20$ & 0.610 & Valid \\
\hline 21 & & BK_Total & 1 & Valid \\
\hline
\end{tabular}

\begin{tabular}{|c|c|c|c|c|}
\hline 1 & \multirow{8}{*}{ Stres Kerja (X2) } & SK1 & 0.573 & Valid \\
\hline 2 & & SK2 & 0.618 & Valid \\
\hline 3 & & SK 3 & 0.726 & Valid \\
\hline 4 & & SK 4 & 0.724 & Valid \\
\hline 5 & & SK 5 & 0.760 & Valid \\
\hline 6 & & SK 6 & 0.728 & Valid \\
\hline 7 & & SK7 & 0.740 & Valid \\
\hline 8 & & SK_Total & 1 & Valid \\
\hline 1 & \multirow{9}{*}{ Efektivitas Kerja(Y) } & Y1 & 0.651 & Valid \\
\hline 2 & & $Y_{2}$ & 0.642 & Valid \\
\hline 3 & & 0.729 & Valid & \\
\hline 4 & & Y4 & 0.849 & Valid \\
\hline 5 & & $\mathrm{Y} 5$ & 0.888 & Valid \\
\hline 6 & & Y6 & 0.788 & Valid \\
\hline 7 & & $Y 7$ & 0.753 & Valid \\
\hline 8 & & Y8 & 0.756 & Valid \\
\hline & & Y_Total & 1 & Valid \\
\hline
\end{tabular}

Data Source: Processed from the Questionnaire, 2021

Based on Table I It is known that each indicator (item) in eachvariable independent work culture and work stress, as well as thevariable dependent work effectiveness has a result of r-count greater than r-table 0.212 so that the indicators (items) used in this research variable can declared valid and can be used as items in data collection.

\section{Realibility Test}

The reliability test is intended to test the consistency of the questionnaire in measuring a similar construct or the stability of the questionnaire if it is used over time (Ghozali, 2016). In this case, if the Realibility Coefficient (Alpha) value is greater than $0.60 \quad(\alpha>0.6)$, then the variables and items being measured can be trusted or relied upon (Sugiyono, 2017).

This study uses 3 variables, namely thevariable independent work culture and work stress, and thevariable dependent work effectiveness. The results of the reliability test of each variable can be seen in table 4.2 below.

Tabel II Reliability Test Results for Research Instruments Variable

\begin{tabular}{lcccc}
\hline \multicolumn{1}{c}{ Indikator } & $\begin{array}{c}\text { Cronbach's } \\
\text { Alpha }\end{array}$ & Cutt Off & $\begin{array}{c}\text { N of } \\
\text { Case }\end{array}$ & Keterangan \\
\hline Budaya Kerja $\left(\mathrm{X}_{1}\right)$ & 0,951 & $>0,60$ & 60 & Reliabel \\
Stress Kerja (X $\left.\mathrm{X}_{2}\right)$ & 0.821 & $>0,60$ & 60 & Reliabel \\
Efektivitas Kerja (Y) & 0.88 & $>0,60$ & 60 & Reliabel \\
\hline
\end{tabular}

Data Source: Processed from the Questionnaire, 2021

Based on Table II we can see that the Cronbach's Alpha value of work culture is $0.951>0.6$, which means that the work culture variable meets the reliability requirements. The Cronbach's Alpha value of work stress is $0.821>0.6$, which means that the work stress variable also meets the reliability requirements. Likewise, the Cronbach's Alpha value of work effectiveness is 0.88>0.6, which means that the work effectiveness variable meets the reliability requirements. Thus, the overall variables in this study meet the reliability test.

Published By: Blue Eyes Intelligence Engineering \& Sciences Publication 


\section{Normality test}

Used to determine the dependent variable, independent or both normally distributed, close to normal or not. This normality test can be viewed graph normal probability plot, through the classical assumption thatobtained normal probability plots as follows.

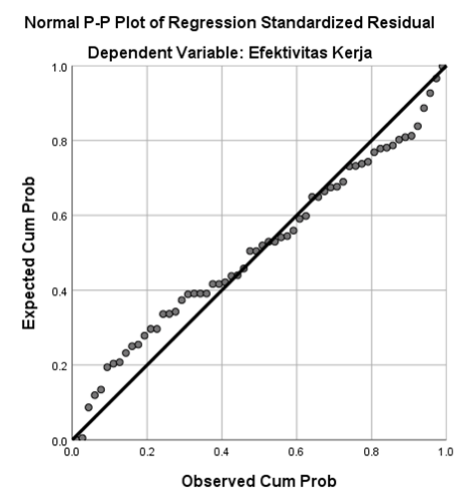

Graph I Normality Test of Research Data with Normal P Plot

Data Source: Processed from the questionnaire, 2021

Based on the appearance of the Graph I Normal Probability plotabove, it can be concluded that the dots are seen spreading around the diagonal line, and the direction of the distribution follows the diagonal line. Thisgraph normal probability plot shows that the data used meets the assumptions of normality and is feasible to use.

\section{Multicollinearity Test}

Thei higheri the itolerance value, the lower the degree of collinearity that occurs, while for VIF, the lower the VIF, the lower the degree of collinearity that occurs. The limit of the maximum value of VIF which is usually used to justify the presence of collinearity is 10 . The definition of the multicollinearity assumption is a condition in which there is an almost perfect linear relationship between the independenti variables in the model

Tabel III Multicollinearity Test Results

\begin{tabular}{|c|c|c|c|c|c|c|c|c|}
\hline \multicolumn{9}{|c|}{ Coefficients $^{\mathrm{a}}$} \\
\hline \multirow[b]{2}{*}{ Model } & & & & $\begin{array}{c}\text { Standardiz } \\
\text { ed } \\
\text { Coefficient } \\
\mathrm{s}\end{array}$ & $\mathrm{t}$ & Sig. & $\begin{array}{l}\text { Collinearit } \\
\text { y Statistics }\end{array}$ & \\
\hline & & & & \begin{tabular}{|l|} 
Beta \\
\end{tabular} & & & Tolerance & VIF \\
\hline 1 & $\begin{array}{l}\text { (Constant) } \\
\text { (a) }\end{array}$ & 26,56 & $\begin{array}{ll}, 894 \\
\end{array}$ & & $\begin{array}{l}, 428 \\
\end{array}$ & 0 & & \\
\hline & $\begin{array}{l}\text { Budaya } \\
\text { Kerja }\end{array}$ & 0,18 & 0,043 & 0,445 & 4,222 & 0 & 0,761 & 1,314 \\
\hline & Stres Kerja & $-0,607$ & 0,164 & 0,39 & $-3,699$ & 0 & 0,761 & 1,314 \\
\hline
\end{tabular}

Data Source: Processed from the questionnaire, 2021

Based on Table 4.6 shows that there is no multicollinearity symptom where the VIF value for the work culture variable is $1.314<10.0$. Likewise, the work stress variable with a VIF value of $1.314<10.0$, which means that there are no symptoms of multicollinearity.

\section{Heteroscedasticity Test}

Heteroskidastity Testaims to test whether a regression model occurred inequality residual variance from one observation to another observation. If the variance from the residual of one observation to another observation is still called homoscedasticity, while for different variances it is called heteroscedasticity.

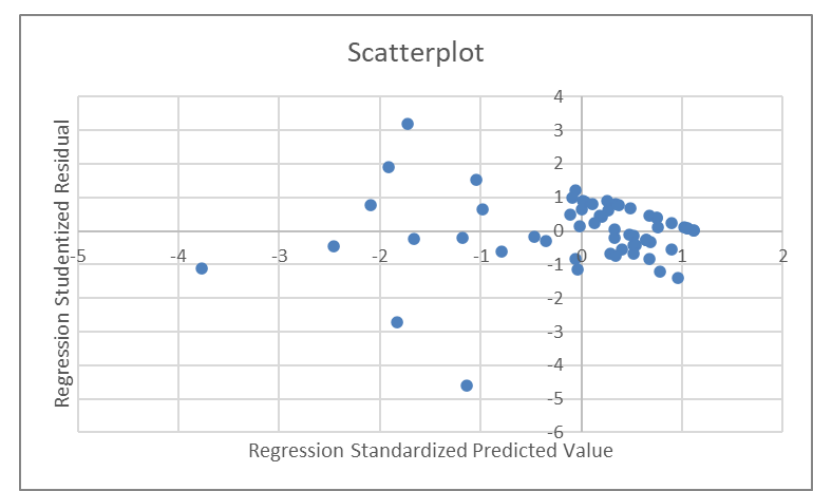

Grafik II Uji Heteroskedastisitas Data Penelitian dengan Grafik Scatter Plot

Data Sources: Processed from the Questionnaire, 2021

Based on Figure II it shows that the distribution of points on the heteroscedasticity test results of the data does not form a certain pattern. Thus it can be concluded that the data in this study are free from heteroscedasticity.

\section{Results of Multiple Linear Analysis Multiple}

Multiple linear regression analysis was used to measure the effect of more than one predictor variable (independent variable) on the dependent variable. In this study, the independent variable is work culture (X1) and work stress (X2), and the dependent variable is work effectiveness (Y). Here are the results of the linear analysis output:

Tabel V Test Results of Multiple Linear Regression Analysis X1 and X2 Against Y

\begin{tabular}{|c|c|c|c|c|c|c|}
\hline \multicolumn{7}{|c|}{ Coefficients $^{\mathrm{a}}$} \\
\hline Model & & & & $\begin{array}{c}\text { Standardized } \\
\text { Coefficients } \\
\text { Beta }\end{array}$ & t & Sig. \\
\hline \multirow[t]{3}{*}{1.} & (Constant) & 26,56 & 4,894 & & 5,427 & 0,000 \\
\hline & $\begin{array}{l}\text { Budaya } \\
\text { Kerja }\end{array}$ & 0,179 & 0,042 & 0,444 & 4,221 & 0,000 \\
\hline & $\begin{array}{l}\text { Stres } \\
\text { Kerja }\end{array}$ & $-0,606$ & 0,164 & $-0,389$ & $-3,699$ & 0,000 \\
\hline
\end{tabular}

Data Sources: Processed from the Questionnaire, 2021

\section{Hypothesis}

Test Results Significant Test Results Individual Parameters (t test)

T-test analysis was conducted for the individual significance of the independent variables on the dependent variable by assuming the other independent variables were considered constant. For the purposes of this test, by seeing whether the values of the coefficients obtained are real or not between $t$ count at the $5 \%$ confidence level or $=0.05$.

Based on the results of the t-test analysis calculations in Table 4.8 can be described as follows:

1. Analysis of the influence of work culture (X1) on work effectiveness (Y), has a beta value of 0.444 with a significant value of 0.000 which is smaller than 0.05 . This means that the work culture variable has a positive and significant effect on work effectiveness. Thus this means that Ho1 is accepted and Ha1 is rejected.

Published By:

Blue Eyes Intelligence Engineering

\& Sciences Publication

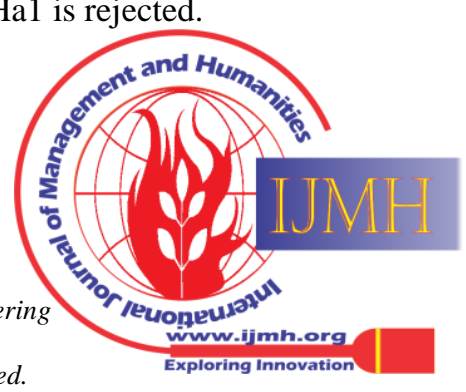


2. Analysis of the effect of work stress (X2) on work effectiveness $(\mathrm{Y})$, has a beta of -0.389 with a significance value of 0.000 which is smaller than 0.05 . This means that the work stress variable has a significant negative effect on work effectiveness so that $\mathrm{H} 2$ is proven to have the influence of the independent variable and the dependent variable.

\section{Model Feasibility Test Results (F Test)}

The F statistical test analysis was conducted to test the effect of work culture (X1), work stress (X2) on work effectiveness $(\mathrm{Y})$. The criterion in this test is if the level of significance is $<0.05$.

Table VI Feasibility Test Results for the F X1 and X2 against $\mathbf{Z}$

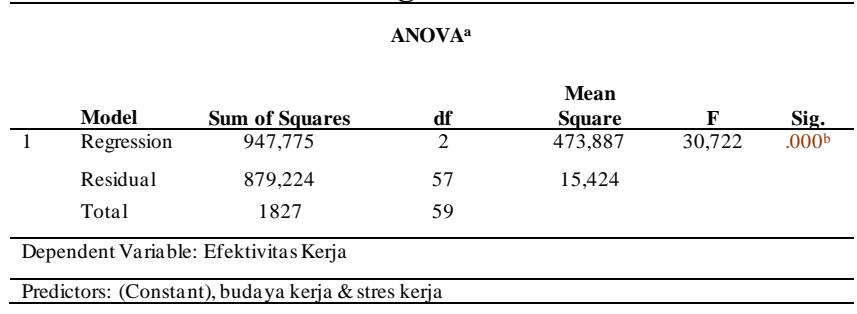

Data Sources: Processed from the Questionnaire, 2021

Based on table VI, F value iscalculated 30,722 with a significance level of 0,000 . Thus the value of Fcount 30,722 is more basic Ftable $(\mathrm{dF}=3: 96)=3.99$ and sig.F 0,000 which means smaller than 0.05 . So it can be concluded that thevariables independent included in the regression model, namely work culture (X1) and work stress (X2), simultaneously (together) affect work effectiveness (Y).

\section{RESEARCH RESULTS FOR EACH VARIABLE}

\section{Effect of Work Culture on Work Effectiveness Work}

Culture has a positive and significant effect on work effectiveness. From the research results obtained coefficient for work culture variable of 0.206 with a significant value of 0.000 where this value is known to be significant at the 0.05 significance level because it is smaller than 0.05 . Thus, the results of this study support the first hypothesis $\left(\mathrm{H}_{1}\right)$ that there is a positive and significant influence of work culture on work effectiveness

\section{Effect of Job Stress on Work Effectiveness Job}

Based on the statistical results in table 4.8 shows that the second hypothesis is accepted, which means that work stress has a negative and significant effect on work effectiveness. Based on the value of the work stress coefficient of -0.606 which indicates that the direction of the relationship between work stress and work effectiveness is negative. Meanwhile, the significance value between work stress and work effectiveness is $0.000<$ 0.05 . This means that the higher the level of work stress experienced by employees, the lower the work effectiveness of employees.

\section{Recapitulation of Research Results}

Based on the results of the discussion that has been made above, it can be seen that the results of the recapitulation of research results are as follows:

\section{Recapitulation of Research}

\begin{tabular}{|c|c|}
\hline $\begin{array}{l}\text { Hipotesis } \\
\end{array}$ & Hasil Penelitian \\
\hline $\begin{array}{l}\text { Ho: Work Culture on w ork effectiveness is } \\
\text { accepted } \\
\text { Ha: Work Culture on w ork effectiveness is } \\
\text { rejected }\end{array}$ & $\begin{array}{l}\text { H1 : Work culture has a } \\
\text { positive and sgnificant effec } \\
\text { on work effectiveness }\end{array}$ \\
\hline $\begin{array}{l}\text { Ho: Job stress on work effectiveness is rejected } \\
\text { Ha: Job stress on work effectiveness is accepted }\end{array}$ & $\begin{array}{l}\text { H2: Job stress has a negative } \\
\text { and significant effect on wor } \\
\text { effectiveness }\end{array}$ \\
\hline
\end{tabular}

Data Sources: Processed from the Questionnaire, 2021

\section{CONCLUSIONS AND SUGGESTIONS}

\section{Conclusion}

Based on the results of the analysis and discussion in the previous chapter, this research can be concluded as follows: 1. Work culture has a positive and significant influence on work effectiveness at PT Trakindo Utama

2. Work stress has a negative effect on work effectiveness at PT Trakindo Utama

\section{Suggestions}

Based on the results of the research, discussion, and conclusions above, the suggestions that the researchers propose are as follows:

1) It is recommended for further researchers to use other mediating variables to connect the dependent variable and the independent variable in order to enrich the repertoire of research that has been carried out.

2) The company is expected to pay more attention and provide policies to employees so that they continue to apply the work culture.

Then, management should pay more attention to employees who experience work stress, because it has been proven that work stress has a significant effect on work effectiveness.

\section{REFERENCES}

1. Abdullah, S. (2018). Bongaya Journal for Research in Management. 1(April), 51-56.

2. Afandi, M. Yazid. 2009. Fiqih Muamalah dan Implementasinya dalam Lembaga Keuangan Syari'ah.Yogyakarta: Logung Pustaka.

3. Andriani, R., Kusuma, R., \& Zulfiani, D. (2019). Korelasi Budaya Kerja Dengan Efektivitas Kerja Karyawan Bagian Kompartemen Investasi Pengembangan Pada PT. Pupuk Kalimantan Timur di Kota Bontang. Jurnal Administrasi Negara, 7, 8960-8970.

4. Anwar, Suroyo. (2009). Pemahaman Individu, Observasi, Checklist, Interview,.

Kuesioner dan Sosiometri. Yogyakarta: Pustaka Pelajar

5. Anwar Prabu Mangkunegara, 2013. Manajemen Sumber Daya Manusia Perusahaan.

Bandung: PT. Remaja Rosda Karya

6. Azwar, M. (2016). PENGARUH KEPEMIMPINAN TRANSAKSIONAL DAN BUDAYA ORGANISASI TERHADAP EFEKTIVITAS KERJA PADA BALAI DIKLAT KEHUTANAN PEKANBARU. Vol. VIII. No. 3 Sep 2016, VIII(3).

7. Cakra. (2020). Pengaruh budaya kerja terhadap efektivitas pelayanan publik kantor desa timoreng panua kecamatan panca rijang kabupaten sidenreng rappang. 8(X), 148-154.

8. Firmansyah, M. A., \& Ramadhani, N. W. (2018). PENGARUH LINGKUNGAN KERJA DAN BUDAYA ORGANISASI TERHADAP EFEKTIVITAS KERJA KARYAWAN BAGIAN PRODUKSI DI PT. ANEKA JASUMA .... In JURNAL EKSEKUTIF (Vol. 15, Issue 2, 264 -277) http://jurnal.ibmt.ac.id/index.php/jeksekutif/article/download/183/1 $\underline{64}$

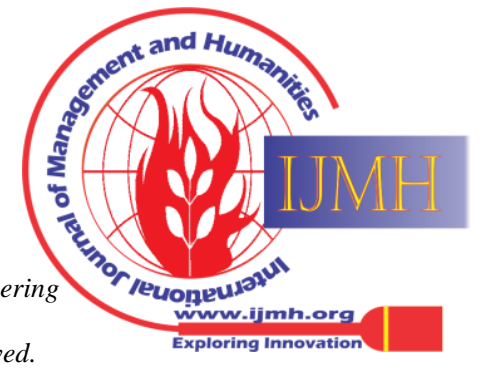


9. Fitri, Y. E. (2019). Peran Pengawasan dan Budaya Organisasi Terhadap Efektivitas Kerja Pegawai Sekolah Tinggi Ilmu Kesehatan (STIKES) Al-Ma'arif Baturaja.

10. Fransiska, R. (2019). Al-kalam issn 2355-3197. 6(1), 89-105.

11. Hanafi, A., Zunaidah, -, \& Ulfa, M. (2018). The Effect of Job Stress Toward Employee Performance Through Job Satisfaction of PT Muara Alam Sejahtera Employees. International Journal of Scientific and Research Publications (IJSRP), 8(8), 1-5. https://doi.org/10.29322/ijsrp.8.8.2018.p8002

12. Handoko,t.Hani.2014.Manajemen Personalia \& Sumber Daya Manusia .Edisi Kedua.Cetrakan Ke 21.Yogyakarta:BPFE-yogyakarta Hidayat, A.A. (2017). Metode Penelitian Keperawatan dan Kesehatan Jakarta: Salemba Medika.

13. Imai, Masaaki. 2008. The Power of Kaizen, Think. Yogyakarta

14. Irwana, A. (2015). Kepemimpinan Visioner Kepala Sekolah Dan Kinerja Guru Terhadap Efektivitas Sekolah Di Sekolah Dasar. Jurnal Administrasi Pendidikan UPI, 22(2), 104-119. https://doi.org/10.17509/jap.v22i2.5392

15. Ghozali, Imam. 2016. Aplikasi Analisis Multivariete Dengan Program IBM SPSS 23

16. (Edisi 8). Cetakan ke VIII. Semarang : Badan Penerbit Universitas Diponegoro.

17. Kartika, H., \& Hastuti, T. (2011). Analisa Pengaruh Sikap Kerja 5S dan Faktor Penghambat Penerapan 5S Terhadap Efektivitas kerja Departemen Produksi di Perusahaan Sepatu. Jakarta: Jurnal Ilmiah PASTI, V(1), 47-54.

18. Kreitner, Robert dan Angelo Kinicki. 2014. Perilaku Organisasi. Edisi 9. Buku 1.

Jakarta: Salemba Empat.

19. Kultsum, U. (2017). Pengaruh Lingkungan Kerja Dan Budaya Organisasi Terhadap Efektivitas Kerja Melalui Motivasi Kerja Sebagai Variabel Intervening Pada Pt. Trasti Global Konverta. Journal of Business Studies, 2(2), 121-132.

20. Laswirtani, N. K., \& Nirma Lestari, C. (2019). EFEKTIVITAS PELAYANAN ( Studi Kasus Pada PT Bank Central Asia Cabang Gianyar dan Klungkung ). 209-229.

21. Listiani, T. (2010). Penerapan Konsep " $5 \mathrm{~S}$ " dalam Upaya Menciptakan Lingkungan Kerja yang Ergonomis di STIA LAN Bandung. Jurnal Ilmu Administrasi: Media Pengembangan Ilmu Dan Praktek Administrasi, 7(3), 05.

22. Markus. (2020). Pengaruh Pembagian Kerja Dan Pengawasan Terhadap Efektivitas Kerja Pegawai Pada Badan Kepegawaian Dan Pengembangan Sdm Kota Pagar Alam.

23. Melani, P. D., Warso, M. M., \& Haryono, A. T. (2016). Pengaruh komunikasi organisasi, stres kerja, dan motivasi kerja terhadap efektivitas kerja karyawan dengan kepuasan kerja sebagai variabel intervening pada PT Ungaran Sari Garments iii pringapus unit pringapus iii departemen sewing assembly line. Journal of Management, 2(2), 1-10.

24. Moeljono, Djokosantoso. 2015. Cultured: Budaya Organisasi dalam Tantangan.

Jakarta: Elex Media Komputindo.

25. Narpati, B. (2017). Pengaruh Disiplin Kerja dan Pengawasan Efektivits Kerja Karyawan pada PT.Bank Mandiri (Persero) Tbk Cabang Bekasi Juanda. In Jurnal Kajian Ilmiah (Vol. 17, Issue 1, pp. 1-11).

26. Nedaee, T., Alavi, K., \& Ramezani, Z. N. (2012). Employees' effectiveness. World Applied Sciences Journal, 18(10), 1400-1411. https://doi.org/10.5829/idosi.wasj.2012.18.10.1316

27. Olaimat, D. (2017). The Moderating Effect of Organizational Support on the Relationship between Job Stress and Employee Performance in. European Journal of Business and Management, 9(14).

28. Osada, Takashi. (2014). Sikap Kerja 5S. Jakarta: PPM.

29. Philips, John. M. Pincus and S.O Rego. (2013). "Earnings Mangement : New Evidence Based on Deffered Tax Expanse.” The Accounting Review. No.78. Hlm. 491-521.

30. Prawirohardjo, H. (2012). Pengaruh Kejelasan Peran, Motivasi Kerja Dan Nilai-nilai Budaya Organisasi Terhadap Efektifitas Pelakasanaan Tugas Karyawan pada Pegawai Pemerintah Daerah Istimewa Yogyakarta. Jurnal Bisnis Dan Ekonomi Vol. 3 No. 1: 47, 56(1), 47-56.

31. Putra, B. H., \& Haryadi, B. (2014). Analisis Prinsip Kerja 5S (Seiri, Seiton, Seiso, Seiketsu, Setsuke) Pada CV. Kokoh Bersatu Plastik, Surabaya. $\quad$ Agora, 2(2), 723-730. http://publication.petra.ac.id/index.php/manajemen-bisnis/article/vie w/1989
32. Rivai, 2013, Manajemen Sumber Daya Manusia Untuk. Perusahaan, Cetakan

33. Pertama, Raja Grafindo Persada, Jakarta.

34. Robbins, P. Stephen \& Judge, T. A. (2017). Organizational Behaviour, Edisi 13, Jilid 1. Salemba Empat, Jakarta.

35. Rosmala, R. (2019). The Effect of Job Design, Cohesiveness, and Stress to Work Effectiveness of Teachers at PAUD Koja Sub District North Jakarta. Journal of Education and Practice, 10(18), 153-158. https://doi.org/10.7176/jep/10-18-20

36. Schillinger, T., Meyer, T, and Vinz, R. (2010) "Poetry Immersion: reading, writing and performing with secondary students". English in Education.44, (2), 110-125.

37. Sopiah. (2008). Perilaku Organisasi, Yogyakarta: Andi Offset.

38. Steers, Richard M. (2005). Efektivitas Organisasi. Terjemahan Magdalena Jamin.

Jakarta: Erlangga.

39. Sugiarto, C. (2016). Analisis Pengaruh Gaya Kepemimpinan, Komunikasi Internal, Budaya Organisasi Dan Disiplin Kerja Terhadap Efektivitas Kerja Karyawan Koperasi Agrobisnis Tarutama Nusantara (Kopa Ttn) Jember. Bisma Jurnal Bisnis Dan Manajemen, 10(3), 240-251.

40. Sugiyono. (2017). Metode Penelitian Kuantitatif, Kualitatif, dan R\&D. Bandung:

Alfabeta

41. Sulastri, T., . S., \& Istiadi, Y. (2020). Pengaruh Self-Esteem Dan Komunikasi Interpersonal Terhadap Efektivitas Kerja Guru. Jurnal Manajemen Pendidikan, 8(1), 36-40. https://doi.org/10.33751/jmp.v8i1.1962

42. Sutrisno. (2012). Dr.Ir. Benjamin Bukit, MM. || Dr. Tasman Malusa, M.Pd. Dr. Abdul Rahmat., M.Pd. file:///C:/Users/Smile/Downloads/manajemen sumber daya manusia ( PDFDrive.com ).pdf

43. Ulumudin, A. (2013). KABUPATEN GARUT. 53.

\section{AUTHORS PROFILE}

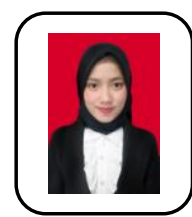

Debby Anggraini SST Student Magister Management, Economic Faculty of Sriwijaya University, Palembang, Indonesia Email: debbyanggraini1095@gmail.com

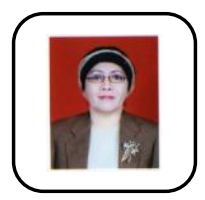

Dr. Hj. Agustina Hanafi, M.B.A Lecturer of Magister Management, Economic Faculty, Sriwijaya University, Palembang Indonesia

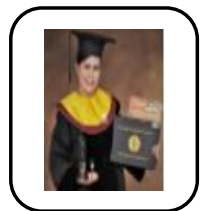

Dr. Yuliani, S.E., M.M Lecturer of Magister Management, Economic Faculty, Sriwijaya University, Palembang Indonesia

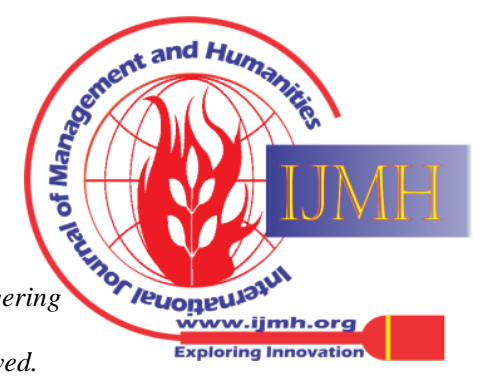

